UDC $621.385 .832 .5: 621.391 .822$

\title{
2. 撮像管のノイズ
}

\author{
東京芝浦電気株式会社 中央研究所中山良 明 \\ 小田川 嘉一郎 \\ 長谷川伸
}

イメージオルシコン, ビジコン, イメージ管を用いた テレビカメラ, フライングスポット装置などのノイズの 理論, 測定法, 実験結果などにつき概説する.

\section{1. イメージオルシコンのノイズ}

イメージオルシコンは二次電子増倍部を内蔵している ので, 増幅器のノイズは無視でき, それ自身のノイズだ けが問題となる.このノイズに関して多くの理論式が導 かれているが，まだ定説はない。ここでは，まず簡単な 理論式をのべてから，厳密な取扱いを行なっている種々 の理論式を検討し，つぎに最近進歩した測定法や実験結 果についてのベる.

\section{1 簡単な理論式}

簡単のため入射光のない場合のノイズを考える．入射 光がある場合もノイズにそれほど大きな違いはない.こ の場合, $S N$ 比は次式で表わされる. $(S / N)_{1}=\frac{\text { ハイライトの出力信号電流尖頭値 } I_{S_{1}}}{}$

ビームのノイズ $\left(\sqrt{\overline{i_{n}^{2}}}\right)$ はショットノイズのみとし， 二次電子増倍部 (利得 $\mu$ )でのノイズの増加率 ${ }^{1}$ )を $k$ (詳 細は後述)とすると

$$
(S / N)_{1}=\frac{I_{S}}{I_{N}}=\frac{\mu i_{s}}{k \mu \sqrt{2 e i_{b} F}} \propto \sqrt{i_{s}} \sqrt{m} \propto \sqrt{m C E_{t a}}
$$

ただし $i_{s}$ はターゲットにランジングする電流, $i_{b}$ はビ 一ム電流, $m=i_{s} / i_{b}$ はビーム変調度, $e$ は電子の電荷,

$F$ は増幅系帯域幅, $C$ はターゲットの容量, $E_{t a}$ はター ゲット電圧. 第 1 図は $E_{t a}$ を変化したときの $m$ と $S N$ 比の実測結果で，（1）式とよく一致する゙2).

\section{2 厳密な理論式}

ある光量が入射したときのノイズを考え， $S N$ 比とし てはつぎの值をとる.

$$
(S / N)_{2}=\frac{\text { ある光量が入射したときの出力電流 }}{\text { (尖頭値) } I_{\Sigma_{2}}}
$$

$I_{N_{2}}$ にはつぎの諸因子が問題となる，入射光子のゆらぎ，

\footnotetext{
"Signa1-to-Noise Ratio of Television Pickup Devices" by Yoshiaki Nakayama, Kaichiro Odagawa and Shin Hasegawa
}

第 17 巻 第 1 号
光電面の光電子放射のゆらぎ, 光電子のコレクタ・メッ シュを通過するさいのゆらぎ，ターゲットガラスからの 二次電子放出比のゆらぎ, 二次電子のメッシニにとられ るときのゆらぎ (透過, 反射, 再分布) ${ }^{16)}$, ターゲット ガラスの蓄積効果, ターゲットガラスの走査側での低速 度電子の反射率3) のゆらぎ，フィールドメッシュの効果， 走査ビーム中のノイズの性質, 走査ビーム内の初速度分 散, 二次電子増倍部でのノイズの増加なぞ.

二次電子増倍部に和けるノイズの増加率 $k_{m}$ は小さい ので(後述), まず二次電子増倍部に入る前の状態の $S N$ 比を取扱か 5 .

以上の諸項目に対する考え方の違いにより多くの説が あり，それらの一部の比較もされている4). ここでは比 較に便利なように、つぎの 2 つの形式で表わす。

$$
(S / N)=\frac{i_{S}}{\sqrt{2 e i_{b} F \cdot k_{1}}}=(S / N)_{0} k_{2}
$$

$$
\text { ただし } \quad(S / N)_{0}=\sqrt{T \cdot n_{p k}}=\sqrt{\frac{T i_{p k}}{2 e F}}
$$

$n_{p k}$ : 1 絵素あたり 1 フレーム時間内に 光電面から放 出される光電子の数

$i_{p k}:$ それを電流で表わしたもの

$T:$ ターゲットメッシュの透過率

(2)式で, もし $k_{1}>1$ の場合は明るい方がノイズが多 いことを示し,$k_{2}>1$ の場合はターゲットに入るところ

第1図イメージオル シコン (M7032) のターゲット電 圧と $S N$ 比（実 测値)

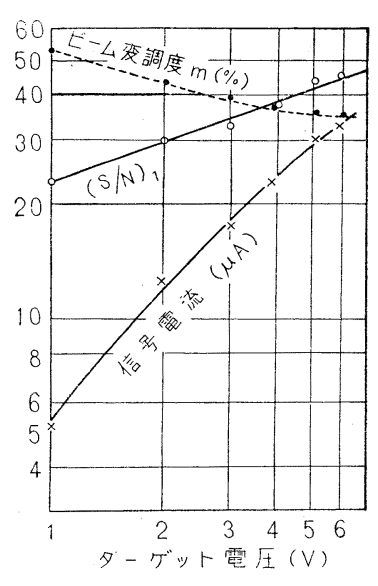

(7) 7 
の $S N$ 比 $(S / N)_{0}$ よりも，出力の方が $S N$ 比がよくな ることを示す.

(1) Bedford の式 ${ }^{5)}$ :

$$
\begin{aligned}
(S / N)_{2} & =\frac{i_{s}}{\sqrt{2 e i_{b} F\left[1+\left(\eta_{t}-1\right) m\right]}} \\
& =(S / N)_{0} \frac{1}{\sqrt{\left(\frac{1}{m}-1\right) \frac{1}{\eta_{t}}+1}}
\end{aligned}
$$

ターゲットの利得を $\eta_{t}$ とし，ターゲット部ではノイズ は付加されないと考学ている， $k_{1}>1 ， k_{2}<1$ となる.

(2) A. A. Rotow の式) :

$$
\begin{aligned}
(S / N)_{2} & =\frac{i_{s}}{\sqrt{2 e i_{b} F \cdot\left(1+\frac{2 m}{\delta-1}\right)}} \\
& =(S / N)_{0} \sqrt{m} \frac{\delta-1}{\sqrt{\delta-1+2 m}}
\end{aligned}
$$

$\delta$ はターゲット面での二次電子放出比を示す.ターダッ 卜面からの二次電子流のノイズが，光電子流のノイズと 全く相関がないと考光ている， $k_{1}>1$ であり， $\delta$ が大き いときは $k_{2}>1$ になり得る.

(3) Theile の式7) :

$$
(S / N)_{2}=\sqrt{\frac{i_{s}}{2 e i_{b} F\left(m \alpha_{0}+\alpha_{1}\right)}}
$$

$\alpha_{0}(\geq 1)$ はターグット部の蓄積電荷のゆらぎ, $\alpha_{1}$ は 走查機構のゆらぎに関する係数である. 暗い場面では $m=0, \alpha_{1}=1$ になるはずで, $\alpha_{1}$ は $m$ の関数と考元ら れるが， $\alpha_{0}, \alpha_{1}$ の内容は明らかにされてない.

(4) DeHaan の式) :

$$
\begin{aligned}
(S / N)_{2}= & \frac{i_{s}}{\sqrt{2 e i_{b} F\left\{\frac{m}{\delta-1}\left(\delta^{2}+\delta+1\right)+1\right\}}} \\
& =(S / N)_{0} \frac{\delta-1}{\sqrt{\delta_{2}+\delta+1+(\delta-1) \frac{1}{m}}}
\end{aligned}
$$

入射光のある場合，もどりどームは減少するが，ビーム 中のノイズは減少しないとしている．また光電子流の， イズが二重に計算されている， $k_{1}>1 ， k_{2}<1$ となる.

(5) B. H. Vine の式9) :

$$
\begin{aligned}
(S / N)_{2}= & -\frac{i_{s}}{\sqrt{2 e i_{b} F\left\{\frac{m}{\delta-1}\left(\delta^{2}-\delta+1\right)+1\right\}}} \\
& =(S / N)_{0} \frac{\delta-1}{\sqrt{\delta^{2}-\delta+1+(\delta-1) \frac{1}{m}}}
\end{aligned}
$$

ビーム中のノイズはへらずに，全部もどるとしている． な敃第 1 ダイノードの二次電子放出比汇よるノイズの増 加分をふくめた式を導いているが，それをふくめない場 合を示した(Weimer ${ }^{10)}$ 参照). $k_{1}>1, k_{2}<1$ となる.

(6) Wuerffel \& Webb の式11):

$$
(S / N)_{2}=\frac{i_{s}}{\sqrt{2 e i_{b} F} F^{-}(1-m)}=(S / N)_{0} \sqrt{\frac{m \overline{(\delta-1)}}{1-m}}
$$

ターダットに蓄積されたノイズを走查ビームで読みとる ときには $600 \mathrm{c} / \mathrm{s}$ くらいの帯域幅を考光ればよいとし, したがってこれを無視して，もどりビーム中のノイズの 又を考觉ている. $k_{1}<1$ となり，明るい方がノイズは少 ない. $\delta$ 大では $k_{2}>1$ になり得る.

(7) 吉永の式 ${ }^{12)}$ :

$$
\begin{aligned}
(S / N)_{2} & =\frac{i_{S}}{\sqrt{2 e i_{b} F\left\{1-m+\frac{f}{F} \cdot m \cdot \frac{\delta^{2}+\delta+1}{\delta-1} \alpha\right\}}} \\
& =(S / N)_{2} \sqrt{\sqrt{1-m(\delta-1)}}
\end{aligned}
$$

(6) と同様, 映像増幅器の帯域幅 $F$ と, 走査とり出し

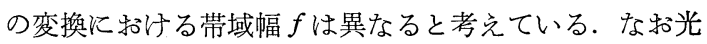
電子流のノイズと，それがターダットで増幅された值と を無相関として加え合わせている，ただし 係数 $(\fallingdotseq 0.78) . f \ll F$ では $k_{1}<1$, また $\delta$ 大では $k_{2}>$ 1 になり得る.

(8) John の式13):

$$
(S / N)_{2}=\frac{i_{s}}{\sqrt{2 e i_{b} F(m \delta+1)}}=(S / N)_{0} \sqrt{\frac{m(\delta-1)}{m \delta+1}}
$$

走查ビーム中のノイズは全部もどると仮定し，ターゲッ ト部のઈのバラッキによるノイズの付加分は加えてある. $k_{1}>1, \quad k_{2}<1$ となる.

(9) Ramberg の式14):

$$
\begin{aligned}
S ! N= & \frac{i_{s}}{\sqrt{2 e i_{b} F\left[\left\{(\delta-1)+\frac{\delta}{\delta-1}\right\} m+\left\{\left(\frac{m}{1-\delta^{\prime}}\right)^{2}\right.\right.}} \\
& \left.\left.\left(1-\frac{2\left(1-\cos x_{c}\right)}{x_{c}}\right)^{2}-2\left(\frac{m}{1-\delta^{\prime}}\right)\left(1-\frac{s_{i} x_{c}}{x_{c}}\right)+1\right\}\right]
\end{aligned}
$$

分母の前の項はターゲットの部分のノイズで Vine の式 と一致する. 後の項はビームがターゲットにランジング するときの反射率 $\delta^{\prime}$ を考慮し, 矩形のビームとして計 算したときのもどりのビーム中のノイズである，計算の 結果， $k_{1}$ は 1 よりも相当大きい值が示されている.

\section{考 察}

上の諸説の考光方の大きな相異点は，（1）ターゲッ トでのノイズの加方，（2）それを走査読みとるさい の周波数帯域, (3) 走查ビーム中のノイズが全部もど りビームにふくをれるか, などである.

（1）については, 光電変換特性が直線性を保つ範囲 では van der Ziel の方法1) で厳密汇計算すると， $H=$ $\delta+1$ (ただし $H$ は $\delta$ のゆざに関する係数）という仮 定のもとでは, Vine の計算に一致する. しかし実際に は $H=\delta+(1 \sim 3)$ である ${ }^{1)}$.

実験結果では，入射光のある方がノイズが少なく（後 
述)， $k_{1}>1$ になる説はなんらかの修正が必要であろう. また $k_{2}>1$ になるものは, 入力も出力と同じ時間間隔を そっているにもかかわず, 入力よりも $S N$ 比のよい出力 が得られることになり，ちよっと不思議である.

実験と合了理論を出すには, 光量による $\delta$ の変化 ${ }^{15)}$, ターゲットメッシュでの電子の反射率16)なども考慮しな ければならないかも知れない。

二次電子增倍部に招けるノイズの増加率 $k_{m}$ は, ダイ ノードの二次電子放出比を初段 $\delta_{1}$, 第 2 段以降 $\delta$ とする 々

$$
k_{m}=\sqrt{\left(H_{1}+\frac{H-\delta}{\delta-1}\right) \frac{1}{\delta_{1}}}
$$

となる. ふつう $H-\delta=(1.2 \sim 1.5) \delta$ である1). むし $\delta$ のばらつきの確率分布をポアソン分布と仮定すると（実 際はそうはならないが） $H-\delta=1, H_{1}-\delta_{1}=1$ となり

$$
k_{m}^{\prime}=\sqrt{1+\frac{\delta}{\delta-1} \frac{1}{\delta_{1}}}
$$

そなって, 吉永の式 ${ }^{12)}$ と一致する.（3)，(4)式の計算 結果を第 2 図に示す.

\section{3 イメージオルシコンのノイズの測定法}

イメージオルシコンのノイズに関して, 上記のように 種々の理論がのべられているのは, それらを検討する適 当な測定法が最近までなかったためである. 従来はオシ ロスコープの信号波形を観察し, それ江重罝している “くさむら”のようなノイズの振幅を判読する方法があ ったが, 個人差や測定条件による誤差が大きく, 周波数 特性も測れなかった。

Bedford ${ }^{5)}$ は等価ノイズ二極管を用いて絶対值を求め ようとしたが, 広帯域の増幅器で測定するため, 帰線期 間の信号や誘導が入り, 誤差を生じやすい.

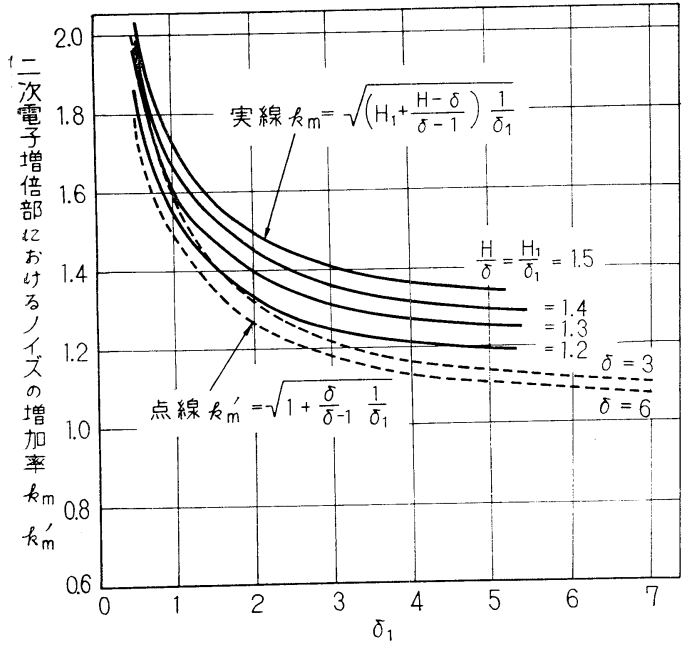

第 2 図 二次電子增倍器のノイズ增加率 $k$ 飞対する第 1 ダイノードの二次電子放出比 $\delta_{1}$ の影響(計算值)

第 17 巻 第 1 号

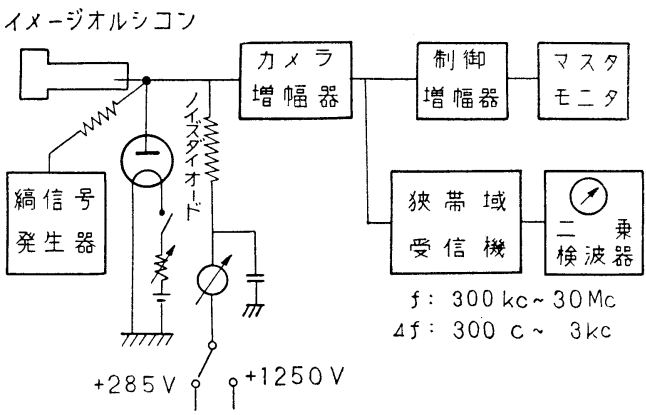

第3図イメージオルシコンのノイズ測定法

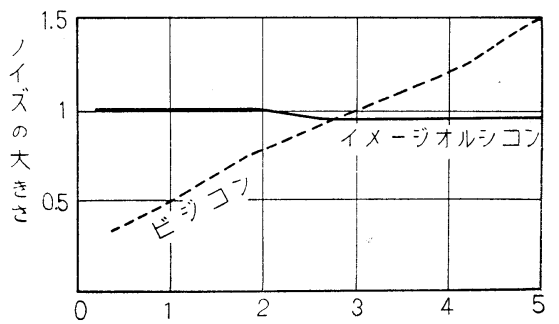

周 波数 (MC)

第 4 図イメージオルシコンとビジコンの周波数特 性（ホワイトノイズで規準化したもの）

Weaver ${ }^{17)}$ は上の欠点を除去して带域幅は $1 \mathrm{kc}$ 程度 の狭帯域にし, テレビ水平走査周波数の高調波間のノイ ズのみの部分を選別して，別のノイズ源と比較した。 一 般にテレビ信号の $S N$ 比を測定するのに便利な巧みな方 法であるが, 前置増幅器の出力で $S N$ 比を測るとその周 波数特性がイメージオルシコンのノイズに付加されてし ま5. Fix, Kaufman は真空管電圧計と帯域幅 $50 \mathrm{kc}^{18)}$, $5 \mathrm{kc}^{19)}$ の增幅系とを組合わせて測定を行なった.

中山, 小田川 ${ }^{200}$ は增幅系の周波数特性にもとづく誤差 を除くため, Weaver の方法とイメージオルシコンの出 力電極に並列に標準ノイズ源を插入する方法を組合わせ

(第 3 図)，安定にノイズの周波数特性や入射光を入れ たときの特性なぞを測定した (次節参照).

S. W. Edwardson'21) はテレビのはめこみ技術を利用し て，その中のノイズを正弦波発生機の出力と比較した. 中村, 海老沢 ${ }^{22}$ はこれでイメージオルシコンのノイズの 測定を行なえることを示したが，広帯域增幅器を用いて 招り, 周波数特性は測定しにくい。

\section{4 実験結果}

以上のべたように，正確な測定法が工夫されたのが最 近なので，発表された実験結果は多くない。第4 図は Fix ${ }^{18)}$ が測定した周波数特性である.

第 5 図は筆者の測定した結果で, 縦軸は入射光がない ときの出力電流中のノイズ $I_{N_{1}} を \mu \sqrt{2 e i_{b}} F$ で除した 值である ${ }^{15)}$.この值はビーム中のノイズをショットノイ ズ $\sqrt{2 e i_{b}} \bar{F}$ のみとすると, 二次電子增倍部でのノイズ 


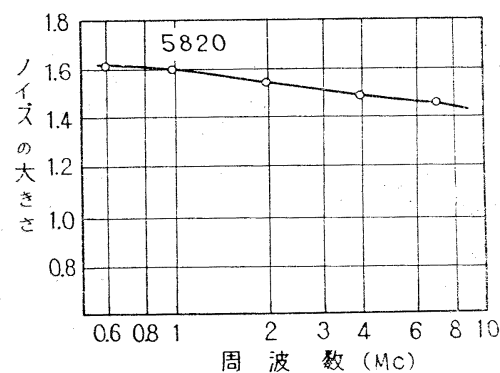

第 5 図イメージオルシコン 5820 のノイズの周波数 特性（ショットノイズで規準化したもの）．縦 軸の值は二次電子堌倍部でのノイズの增加率を 示すであろ（本文参照）

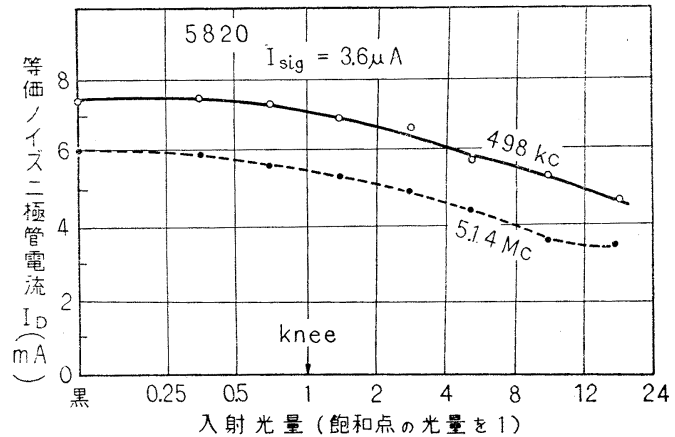

第 6 図入射光量とノイズの関係

の增加率 $k_{m}$ を示すことになる ((1) 式参照). この值が 1.6 1.4 程度で，これが全部二次電子增倍部で付加さ れたものか，あるいはビーム自身がショットノイズより もいくらか多くのノイズをもっているのかが問題である が，主として前者がきいていると思われる，关机は実効 的な $\delta_{1}$ を実験により求めたところ $1.2 \sim 1.5$ であり,

（3）式と第 2 図から，二次電子増倍部でのノイズの增 加率が 1.4 1.65 の間汇要ると考光られ，第 5 図の実 験とよく一致するからである、な就第 5 図は 5820 を 5 本測定した平均值を示したが，平均值からのばらつきは $\pm 3 \%$ 程度しかなかった。

従来, イメージオルシコンのノイズの周波数特性は, ショットノイズと同様平らであるとされていたが，高周 波の方がいくらか少ないことが第 4 図，第 5 図からわか る.この原因は扮そらく, 走査部や二次電子增倍部での 電子の走行時間がきいているためであろう.

明るさとノイズの関係の一例を第 6 図に示す20). これ は前述の諸理論を検討する 1 つの根拠となるが，明るい 方が普通若干ノイズが減っている. Theileら ${ }^{23)}$ も出力波 形の写真観察により明部でのノイズの減少を認めている。 なお Weimer ${ }^{10)}$ が実験值を考虑して計算した $S N$ 比の 值を第 7 図泟示与.

$10(10)$

\section{2. ビジコンのノイズ}

ビジコンの場合は出力信号が小さいので, 出力信号中 のノイズの棌か炕負荷抵抗 $R$ の熱擾乱ノイズ, 增幅器の 初段真空管のノイズ(等価ノイズ抵抗 $\left.R_{e}\right)$ なぞを考党な ければならない。

(1) Haan ${ }^{8)}$ の式:

$$
\begin{array}{r}
S / N=\frac{i_{s}}{\sqrt{2 e i_{\mathcal{S}}(\sigma+1) F+\frac{4 k T}{R} F+\frac{4 k T}{R^{2}} R_{e} F}} \\
\left(1+\frac{4}{3} \pi^{2} R^{2} C^{2} F^{2}\right)
\end{array}
$$

$i_{s}$ はビジニンの出力電流, 分母の第 1 項は信号電流中の ノイズ，第 2 項は $R$ の熱ノイズ，第 3 項は初段管のノイ ズ， $C$ は $R$ 注並列に入っている漂遊容量, $\sigma$ は 1 個の Photon により出力電極に流れだす電子の数である.

(2) Theile ${ }^{7)}$ の式 :

$$
S / N=\frac{i_{s}}{\sqrt{2 e \sigma_{1} i_{s} F+\frac{4 k T}{R} F+4 k T \frac{4 \pi^{2}}{3} R_{e} C^{2} F^{3}}}
$$

$R_{e} \ll R$ と近似して拉り, 分母の各項は前と同様の内容 である、ただし， $\sigma_{1}=\alpha_{0}+\alpha_{1} / m$ で， $\alpha_{0}(\geq 1)$ は蓄積電 荷のゆらぎ， $\alpha_{1}$ はビームがターグットにランジングす るときのゆらぎに関するもの, mはビーム变調度である.

(3) Ramberg ${ }^{14)}$ の式:

$$
\begin{gathered}
S / N=\frac{i_{s}}{\sqrt{\left\{2 e\left(i_{s}+i_{d}\right)+\frac{4 k T\left(R+R_{e}\right)}{R^{2}}\right\} \frac{F \int_{0}^{\sqrt{2 k_{0}}} e^{t^{2}} d t}{\sqrt{2 k_{0}}}}} \\
+\frac{4 k T R_{e} \cdot 4 \pi^{2} C^{2} F^{2}}{3}\left\{e^{2 k_{0}}-\frac{1}{\sqrt{2 k_{0}}} \int_{0}^{\sqrt{2 k_{0}}} d t\right\}
\end{gathered}
$$

$i_{s}+i_{d}$ の項は信号電流と暗電流がショットノイズのみを ふくもとし， $k_{0}$ によりビジコンのレスポンス，增幅系 の特性の影響を考慮している.

実際にはビームを增すとノイズが増大するので，その 点からは Theile の方が適していると思われる。しかし $\sigma_{1}$ の㛜密な内容は詳らかでない。

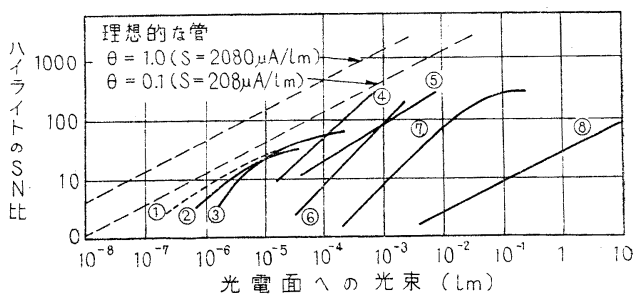

第 7 図 種々の撮像管の $S N$ 比（計算值） (1) イメージ・インテンシファイヤ・オルシコン $(S=150 \mu \mathrm{A} / \mathrm{lm})$ (2) 高利得ターゲットを用いた広間隔の IO $\{S=150 \mu \mathrm{A} / \mathrm{lm}\}$ (3) 高利得ターダットを用いた狭間隔の IO $\{\delta=15, m=0.25\}$

(4) 実験用ビジコン (RCA 74008) ガラス状, (5) 実験用ビジコン (多孔 質), (6) $\mathrm{CPS}$ エミトロン $(S=75 \mu \mathrm{A} / \mathrm{lm})$, (7)アイコノスコープ( $(S=75$ $\mu \mathrm{A} / l \mathrm{~m})$, (8)イメージ・デイセクタ $(S=150 \mu \mathrm{A} / \mathrm{lm})$ 
な劣，ノイズの大体の大きさ計算すると， $F=$ $4.5 \mathrm{Mc}$ として, $\sqrt{2 e i_{s} F}$ は $i_{s}=0.3 \mu \mathrm{A}$ のき約 $6 \times$ $10^{-4} \mu \mathrm{A}, \sqrt{\frac{4 k T_{F}}{R}}$ は $R=100 \mathrm{k} \Omega$ として約 $9 \times 10^{-4} \mu \mathrm{A}$, $\sqrt{4 k T R_{e} \frac{4}{3} \pi^{2} C^{2} F^{3}}$ は $R_{e}=270 \Omega, C=20 \mathrm{pF}$ として約 $14 \times 10^{-4} \mu \mathrm{A}$ となり, Theile の式で $\sigma_{1}=1$ とすれば $S N$ 比 $\div 165$ が得られる.

Neuhauser ${ }^{24)}$ は高周波部分ではノイズが目立ちにく く, アパーチャ補正やガンマ補正ではノイズが目立ちや すくなることを考慮して, 目で見た感じではビジュンカ メラからの信号の $S N$ 比は 100 ぐらいであろうとのべ ている.な括 Fix の測定結果を第4 図にふくめたが, イメージオルシコンと異なり高周波のノイズが多い.

\section{3. その他の撮像装置のノイズ}

前記の撮像管以外に，イメージ管と一般の撮像管との 組合わせ，フライングスポット装置などが使われている.

\section{1 イメージ管と撮像管の組合わせ}

不可視線像または，きわめて暗い像をイメージ管で明 るい可視光像に変換したのち撮像することができる. 入 力像を電子的に輝度增倍して撮像管に導くため, それに ともならノイズ，けい光面の粒状ノイズなどが問題とな る. 種々のイメージ管のうちX線けい光増倍管を用いた ものの及が実用されて扣り ${ }^{25)}$, 主としてそのノイズにつ き考察する.

\section{（1）量子のゆらぎ}

第 8 図 (a) はX線けい光増倍管東芝7018を用いたX線 テレビの系統図, (b) は人体胸部透視程度の条件で, そ の $1 \mathrm{~mm}^{2}, 1 / 30$ 秒あたりの量子数の過程による変化を 示す. 全体の $S N$ 比は量子数最小段階で定まり, 以降の 段階で量子数を増倍しても $S N$ 此は改善されない. 第 8 図ではCがそれにあたる。ノイズのない理想的な系で吸 収量子を 1：1の比で電子に変えて撮像し, 平均出力電 流 $I$ を得たとし, 带域幅 $F$ を $4.5 \mathrm{Mc}$ として $S N$ 比を

$$
\frac{S}{N}=\frac{I}{\sqrt{i_{N}^{2}}}=\sqrt{I / 2 e F}
$$

から求めると，その值は 5.0 となる.

この状態で増倍管出力像の明るさは $9 \times 10^{-4} \mathrm{~lm} / \mathrm{cm}^{2}$ であり，F 1.2 のレンズを拡大率 1.5(集光能率 3.7\%) としてイメージオルシコンに導くと, 光電面照度は 0.14 Lx となる. これはイメージオルシコンには十分な值な ので, 系全体の $S N$ 比はX線量子の数で定まり $S N$ 比 を改善するためにはX線量を增す必要がある.

同じレンズを拡大率 $2 / 3$ (集光能率 $1.6 \%$ ) とし，ビ ジコンに導くと光電面照度は $0.32 \mathrm{Lx}$ になる. $7735 \mathrm{~A}$ を暗電流 $0.02 \mu \mathrm{A}$ で用いると信号電流は $0.02 \mu \mathrm{A}$ 以 下 ${ }^{26)}, 4.5 \mathrm{Mc}$ の帯域幅でビジュンカメラのノイズ電流

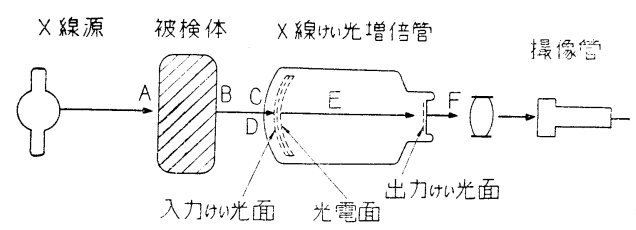

(a)

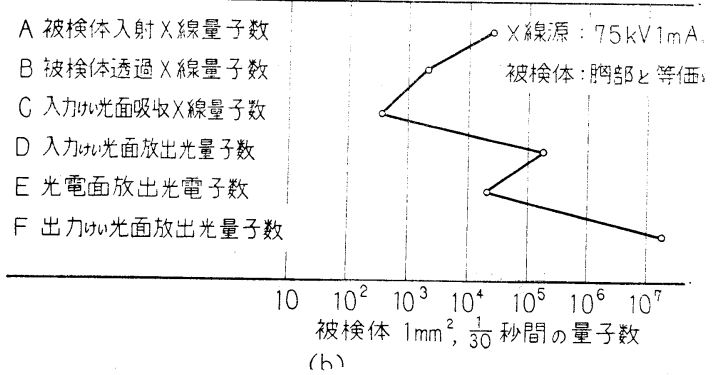

第 8 図 X線テレビカメラ系統図( a), 拈よびその各 段に拈ける平均量子数 $(\mathrm{b})$

は $1.5 \times 10^{-9} \mathrm{~A}$ 程度であり， $S N$ 比は約 10 とる。した がってX線量子ノイズと同程度であり，両者が重なると $S N$ 比は 4.4 となる. 線量を $n$ 倍に増すと $S N$ 比は両 者ともほぼ $\sqrt{n}$ 倍に改善され，系の $S N$ 比もほぼその值 だけ改善される。

(2) 暗電流

光電面からの暗電流は常温で $10^{-15} \mathrm{~A} / \mathrm{cm}^{2}$, したがっ て電子数は 70 個 $/ \mathrm{mm}^{2}$ 秒で, 第 8 図の $\mathrm{E}$ 段階の電子数 約 $5 \times 10^{5}$ よりはるかに小さく, 無視し得る.

（3）壮い光面の粒状

イメージ管の出力けい光像は粒状構造で, 撮像すれば 出力信号にノイズ（受像機では静止）を生ずる。その空 間周波数スペクトルの発表值 ${ }^{29)}$ をテレビ撮像した場合の 周波数スペクトルに直すと第 9 図を得る. この場合, ス ペクトルよりノイズ電圧が重要であるが，その值はわか っていない，けい光膜を微視的に見ると光る粒子の間隙

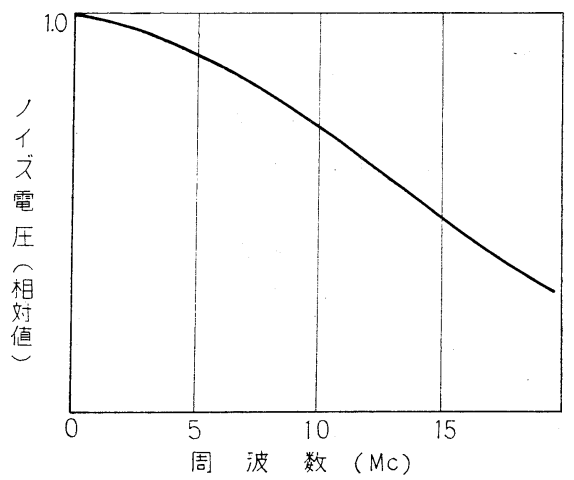

第 9 図 X線けい光増倍管の出力像（直径 $15 \mathrm{~mm}$ ) を テレビ撮像したときのけい光面の粒状構造によ るノイズの周波数スペクトル 


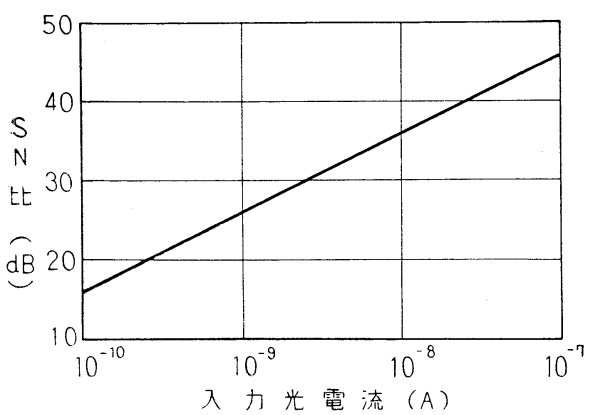

第 10 図 フライングスポット装置の入力光信号 に対する $S N$ 比（帯域幅は $8 \mathrm{Mc}$ )

はさらに輝度が高い，粒子は層状で，各々の輝度は電子 衝撃面からの深さで変わるからである，1絵素にふくま れる粒子数を $n$ とすると, 走査の過程で絵素に 1 個の粒 子が出入するときの信号変化は前記輝度差の $1 / n$ とな り, $S N$ 比は $n$ に比例して改善される. けい光面上で絵 素は $30 \times 30 \mu$ で, $n$ は数個〜10個と推定される.

$\mathrm{X}$ 線テレビでは一般に被検体の浴びるX線量をできる だけ減らすため，（1）の項のノイズが目立つ場合が多い.

【注】最近, 可視光に対しきおめて高感度のイメージ管27), イメージ増 倍部をもつオルシコン28) が研究され，これらはきわめてわずかの大力 光で動作する. この場合, 量子数最少の段階は初段光電面からの放出光 電子で, 光電面の量子効率の改善が要請される.

\section{2 フライングスポット装置}

フライングスポット装置（以下 FSC）は光源ブラウ ン管の一様輝度のラスタ像を被写体に結ばせ, 透過また は反射光を光電子増倍管 (以下 $P M$ ) で増幅する ${ }^{30)}$.

(1) 量子数のユラギによるノイズ

$\mathrm{PM}$ に数百 $\mathrm{V}$ 与えて電子增倍度 $10^{4}$ 程度とし， 5 时ブ ラウン管を組合わせた例では，平均電流は PM の一次 電流 $10^{-8} \mathrm{~A}$, 出力側で $10^{-4} \mathrm{~A}$ 程度で使われる. 光電面 の量子効率は $20 \%$ 以下であるから, 量子数最少の段階 はPM の一次光電流で, 系の量子のユラギによる $S N$ 比 はこの段階でさまる． $F=8 \mathrm{Mc}$ とし (5) 式より $S N$ 比を求めると, 平均の明るさで $36 \mathrm{~dB}, 3$ 倍の明るさの ハイライトで $43 \mathrm{~dB}$ となる. 電子増倍部での $S N$ 比の 低下は $2 \mathrm{~dB}$ 以下の程度である ${ }^{1)}$.

\section{(2) PM の暗電流}

$\mathrm{PM}$ の光電面からはつね熱電子が放出され, その散 射ノイズが前項に重なる. しかし, $\mathrm{Sb}-\mathrm{Cs}$ 面の熱電流は $10^{-15} \mathrm{~A} / \mathrm{cm}^{2}$, 全面積について $10^{-13} \mathrm{~A}$ 以下で, 入力光量 がきわめて小さい場合以外は無視しうる.

（3） PM の負荷抵抗の熱ノイズ

抵抗 $R$ の両端に発生する熱ノイズ電圧は温度 $T{ }^{\circ} \mathrm{K}$, ボルッマン常数 $k$ とすると $\overline{e_{n}^{2}}=4 k T R$ で, $F=8 \mathrm{Mc}$, $T=300^{\circ} \mathrm{K}, R=1 \mathrm{k} \Omega$ ならば $\sqrt{{\overline{e_{n}}}^{2}}=13 \mu \mathrm{V}$ となる. 光
電子放出の散射ノイズは PM の負荷抵抗の両端で平均 1 $\mathrm{mV}$ となり，熱ノイズは無視できる.

（4）けい光面粒状性によるノイズ

光源ブラウン管けい光面の粒状構造はノイズ源となり 得るが，けい光面面積が大きいため無視し得る. 5 时ブ ラウン管の粒状をイメージ管と同じと仮定すれば, 絵素 の面積は後者の約 64 倍, $n$ の值は数 100 となり, これに よるノイズはきわめて小さい.

以上の結果，FSC のノイズの原因は一般に光電子の 散射ノイズで, 入力光電流值と第10図の関係をもつ. 光 電流が $10^{-12} \mathrm{~A}$ 以下では, (2) (3) 項のノイズによって $S N$ 比は急速に悪化するが, ふつう, この範囲は使われ ない14). 実際 FSC の $S N$ 比は明るい場面で $40 \mathrm{~dB}$ 前 後で大体第10図と一致する.

\section{4. むす ひ}

以上，各種の撮像装置のノイズにつき概説した．本文 からわかるようにまだ不明の点も残されて捛り, 今後の 解明がをたれる．終りに懇切な指導ないただいた岡部部 長に感謝の意を表する。

\section{[参 考 文 献]}

1) A.van der Ziel : 雑音 (滰, 飯島, 田宮訳, 近代科学社. 瞆32)

2) 中山, 小田川: 昭 37 電四学連大, 986 頁, または TV 用電子管研委 資料第 166 号 (1962-05)

3) 小田川: 信学誌, 41, 9 (1958) 850-856

4) 武井: テレビ誌, 15,10 (1961) 583-587

5) L.H.Bedford : J.Brit. IRE, (1954-10) 464-474

6) A. A. Rotow : IRE Conv. Rec. Part 3, (1956) $41-49$

7) R. Theile : Adv. in Elec. \& Elec. Phys., 12 (1960), 277290

8) E.F.DeHaan : Adv. in Elec. \& Elec. Phys., 12 (1960), 291-306

9) B.H.Vine : J.SMPTE, (1961, 06), 432-435

10) P. K. Weimer: Adv. in Elec. \& Elec. Phys., 13 (1960), 387-437

11) H. L.Wuerffel \& D.E.Webb : NRL Rep., 4498 (1955-03)

12）吉永: TV 用電子管研委資料 120 号 (1961. 02)

13) Melvin R. St. John : PB-161, 728 (1960-02)

14) E.G. Ramberg: IRE Trans. PGME-12, (1958-12), 58-64

15) 恒岡, 小田川: 昭31 信学全大. 139

16）二宮：NHK 技術研究, 13, No.1 (1961-01), 43-56

17) L.E. Weaver: BBC Eng. Mono. No. 24 (1959)

18) H.Fix, A. Kaufmann : Rundfukt tech. Mit., (1960-04), 60-65

19) H.Fix, A. Kaufmann : radio menter, (1961-02), 114-116

20）中山, 小田川：昭 36 信学全大 264 頁，または TV用電子管研委資 料 147 号 (1961-10)

21) S.W.Edwardson : BBC. Eng. Mono. No. 37 (1961-06)

22）中村, 海老沢：TV 用電子管研委資料 174 号 $(1961 ， 09)$

23) R. Theile, H. Fix : A.E. Ü. 10 (1956-03), 98-104

24) R.G.Neuhauser : J.SMPTE, 70, No.10 (1961), 791-794

25）小川:テレビ誌 15, (1961), 213〜220

26) M. Rome : IRE Int. Conv. Roc., 9, Part 7, (1961), 12 18

27) A.E. Anderson : IRE Trans. NS-7, 2/3 (1960), 133 136

28) G. A.Morton 他: Adv. in Elect. and Elect. Phys., 12, (1960), 183 193

29）長谷川：テレビ誌 15 (1961), 459 463

30) A. J. Baracket: Tele. Tech. 10, 12 (1951), 42 44 